\title{
Bacillus azotofixans sp. nov., a Nitrogen-Fixing Species from Brazilian Soils and Grass Roots
}

\author{
L. SELDIN,* J. D. VAN ELSAS, AND E. G. C. PENIDO \\ Instituto de Microbiologia, Universidade Federal do Rio de Janeiro, Centro de Ciências da Saúde, Bloco I, Ilha do Fun- \\ dão, Rio de Janeiro, RJ, 21.944, Brasil
}

\begin{abstract}
A new species, Bacillus azotofixans, is described. This taxon is based upon 16 soil and root-associated strains that exhibit acetylene-reducing ability and nitrogen-fixing Bacillus sp. strain Hino. B. azotofixans is phenotypically similar to Bacillus polymyxa and Bacillus macerans. However, 13 tests (nitrate reduction; production of acid and gas from xylose, arabinose, lactose, ribose, and glycerol; resistance to lysozyme; liquefaction of gelatin; starch hydrolysis; decomposition of casein and pectin; production of dihydroxyacetone; susceptibility to $B$. polymyxa phages) differentiate it from $B$. polymyxa, and 12 characteristics (spore position; Voges-Proskauer test; nitrate reduction; production of acid and gas from xylose, arabinose, lactose, ribose, and glycerol; growth at $45^{\circ} \mathrm{C}$; hydrolysis of starch; decomposition of pectin; formation of crystalline dextrins) differentiate it from $B$. macerans. The guanine-plus-cytosine contents of five strains ranged from 47.9 to $52.5 \mathrm{~mol} \%$. All strains reduced acetylene much more efficiently than $B$. polymyxa or $B$. macerans. In four strains, nitrogen fixation was confirmed by micro-Kjeldahl analysis of acetylene-reducing cultures. Acetylene reduction was not inhibited by nitrate and was not dependent on yeast extract or thiamin plus biotin. The proposed type strain of $B$. azotofixans is strain P3L-5 (= ATCC 35681).
\end{abstract}

Classically, all Bacillus strains capable of fixing molecular nitrogen were found to belong to Bacillus polymyxa $(7,9)$ or Bacillus macerans (23). In later work, other (nonsymbiotic) nitrogen-fixing Bacillus isolates were tentatively identified as strains of Bacillus circulans (10). To date, no strains of other Bacillus species have been accepted with certainty as nitrogen fixers, although recently it was claimed that several nitrogen-fixing bacilli resembled Bacillus cereus or Bacillus licheniformis (1). Most of the recently isolated nitrogenfixing bacilli have been identified clearly as $B$. polymyxa (1620 ) or $B$. macerans strains (17) or as $B$. polymyxa-like (24) organisms. The original work of Hino and Wilson (9) on nitrogen fixation by a Bacillus strain was done with an isolate that has been classified as an atypical $B$. polymyxa strain $(4,14,19)$. However, the deoxyribonucleic acid (DNA) of this strain revealed a guanine-plus-cytosine $(\mathrm{G}+$ C) content beyond the range reported for $B$. polymyxa, which is typical of $B$. macerans (14).

In a previous report (20), we described 18 acetylenereducing $B$. polymyxa strains from soil and 6 other strains with this property that were tentatively identified as "variants" of $B$. polymyxa. Since then, 10 other acetylenereducing bacilli have been isolated in our laboratory from washed or surface-sterilized roots of different grasses; these strains had properties that were remarkably similar to those of the six aforementioned isolates. In this paper, we describe the characteristics of all of the strains belonging to this group of nitrogen-fixing bacilli.

\section{MATERIALS AND METHODS}

Bacterial strains. The strains used and their sources are listed in Table 1. Of these, six were isolated from two different Brazilian soils and have been described elsewhere (20). A total of 10 new strains were isolated by a modification of the method described by Baldani and Döbereiner (2) from washings of either unsterilized or surface-sterilized macerated roots of different grasses. The suspensions were pasteurized $\left(10 \mathrm{~min}, 80^{\circ} \mathrm{C}\right)$ to select for Bacillus species. Appropriate dilutions were plated onto nitrogen-free thiamine-biotin

\footnotetext{
* Corresponding author.
}

agar (20) and incubated anaerobically. Further enrichment and purification, including two aerobic single-colony reisolation steps, were performed as described by Seldin et al. (20).

Maintenance and propagation of cultures. All strains were stored aerobically at room temperature on GB agar slants (20) supplemented with $1 \% \mathrm{CaCO}_{3}$. Cultures were transferred to fresh slants at 6-month intervals. Long-term preservation of strains was in sterile soil by the method of Gordon et al. (6). Inoculations of media were made from 24 - to $48-\mathrm{h}$ old cultures in GB broth tubes $(20)$ at $32^{\circ} \mathrm{C}$. Unless otherwise stated, the preferred incubation temperature was $32^{\circ} \mathrm{C}$.

Properties of strains. Most cultural and biochemical tests were performed by using the methods and media of Gordon et al. (6). For all tests that required complex media (temperature range of growth, growth inhibition by $\mathrm{NaCl}$ and by $\mathrm{pH}$ 5.7 , hydrolysis of starch, decomposition of pectin and tyrosine, resistance to lysozyme, and liquefaction of gelatin), appropriately adjusted GB solid or liquid media were employed. The basal medium of Gordon et al. (6) was used to test for acid and gas production from carbohydrates. The sugars used were generally in the $\mathrm{D}-(+)$ form, except for $\mathrm{L}-$ $(-)$-arabinose and D-(-)-ribose. Cytochrome oxidase was determined by the standard paper strip Kovacs oxidase test. Cellular morphology, form and position of spores, and swelling of the sporangia were observed by phase-contrast microscopy of wet mounts and on crystal violet-stained smears. Photographs of sporulated cultures were made by using a Zeiss phase-contrast microscope. Capsules were observed on slides prepared by the Duguid method (3). Polyphosphate inclusions were detected in preparations stained with $1 \%$ toluidine blue (3). Motility was observed in fresh wet mounts of young (24-h) bacterial cultures in GB broth. Sensitivity to three different bacteriophages specific for B. polymyxa was tested by the method of Seldin et al. (21).

In all tests, $B$. polymyxa LMD $24.16^{\mathrm{T}}(\mathrm{T}=$ type strain), $B$. polymyxa L, and $B$. macerans NCTC $6355^{\mathrm{T}}$, as well as nitrogen-fixing Bacillus sp. strain Hino, were included as controls. B. polymyxa strains LMD $24.16^{\mathrm{T}}$ and L, B. macerans strain NCTC $6355^{\mathrm{T}}$, and strain Hino were in all aspects similar to their previously published descriptions $(4,6,9)$. 
TABLE 1. Bacillus strains used in this study

\begin{tabular}{|c|c|}
\hline Strain(s) & Source and other information \\
\hline F-100, F-102, F-203, F-215, F-1532 & $\begin{array}{l}\text { From Fundão garden soil, Rio de Janeiro, Brazil; isolation and tentative identification } \\
\text { described by Seldin et al. }{ }^{a}\end{array}$ \\
\hline & $\begin{array}{l}\text { From Itaguaí soil, Rural University of Rio de Janeiro, Rio de Janeiro State, Brazil; de- } \\
\text { scribed by Seldin et al. }{ }^{a}\end{array}$ \\
\hline BE-1, BE-4, BE-5 & $\begin{array}{l}\text { From surface-sterilized roots of Bachiaria ruziziensis var. Kennedy growing at Rural } \\
\text { University of Rio de Janeiro. }\end{array}$ \\
\hline P3E-2, P3E-20, P3E-30 & From surface-sterilized wheat roots from Paraná State, Brazil \\
\hline P3L-3, P3L-5 ${ }^{\mathrm{T}}, \mathrm{P} 5 \mathrm{~L}-4$ & . From wheat roots from Paraná State, Brazil \\
\hline TE-10. & From surface-sterilized wheat roots from Brasília, Federal District, Brazil \\
\hline & $\begin{array}{l}\text { Received from S. Hino, Hiroshima University, Hiroshima, Japan; nitrogen fixer de- } \\
\text { scribed in } 1958 \text { and tentatively classified as } B \text {. polymy } a^{b}\end{array}$ \\
\hline B. polymyxa $\mathrm{LN}$ & Received from J. van der Toorn, Laboratory for Mícrobiology, Delft, Holland \\
\hline & $\begin{array}{l}\text { Received from M. W. Loutit, University of Otago, New Zealand; nitrogen-fixing strain } \\
\text { isolated from soil }\end{array}$ \\
\hline B. polymyxa NRRL B-371(=ATCC 8526) & Received from P. Jurtshuk, Jr., University of Houston, Houston, Tex. \\
\hline B. macerans NCTC $6355^{\mathrm{T}}\left(=\mathrm{ATCC} 8244^{\mathrm{T}}\right)$. & Received from L. Rabinovitch, Instituto Oswaldo Cruz, Rio de Janeiro, Brazil \\
\hline B. macerans P3L-2 ................ & $\begin{array}{l}\text { Source same as strain P3L-3; nitrogen-fixing isolate identified as } B . \text { macerans in our } \\
\text { laboratory }\end{array}$ \\
\hline
\end{tabular}

\footnotetext{
${ }^{a}$ See reference 20 .

${ }^{b}$ See reference 9 .
}

Extraction of DNA and $T_{\mathrm{m}}$ analysis. DNA was extracted by the method of Marmur (12), with the following minor modifications. Cells from $800-\mathrm{ml}$ overnight cultures at $32^{\circ} \mathrm{C}$ were concentrated in $40 \mathrm{ml}$ of $25 \%$ sucrose containing $0.05 \mathrm{M}$ tris(hydroxymethyl)aminomethane and $0.001 \mathrm{M}$ ethylenediaminetetraacetate at $\mathrm{pH} 8.0$ and treated with $1 \mathrm{mg}$ of lysozyme (Calbiochem-Behring) per $\mathrm{ml}$ for $3 \mathrm{~h}$ at $37^{\circ} \mathrm{C}$. Subsequently, the ethylenediaminetetraacetate concentration was increased to $0.01 \mathrm{M}$, and the preparation was treated with $1 \%$ sodium dodecyl sulfate for $30 \mathrm{~min}$ at $65^{\circ} \mathrm{C}$. After several deproteinization steps, the DNA was precipitated and dissolved in $0.1 \times$ standard saline citrate (SSC; $1 \times$ SSC is 0.15 $\mathrm{M} \mathrm{NaCl}$ plus $0.015 \mathrm{M}$ sodium citrate). These partially purified DNA preparations were made $1 \times$ SSC by adding $10 \times$ SSC and then treated with $50 \mu \mathrm{g}$ of ribonuclease $(5 \times$ crystallized; Sigma Chemical Co.) per $\mathrm{ml}$ for $30 \mathrm{~min}$ at $37^{\circ} \mathrm{C}$ and subsequently with $500 \mu \mathrm{g}$ of protease (type p-5005; Sigma) for $2 \mathrm{~h}$ at $37^{\circ} \mathrm{C}$. After additional deproteinization steps, the DNA was precipitated and finally dissolved in $0.1 \times$ SSC; melting temperature $\left(T_{m}\right)$ analysis was performed when the ratio of optical density at $260 \mathrm{~nm}$ to optical density at $280 \mathrm{~nm}$ was 1.8 or higher.

The $\mathrm{G}+\mathrm{C}$ content of the DNA was determined by thermal denaturation, using the method of Marmur and Doty (13), at $260 \mathrm{~nm}$ with a Beckman Acta III spectrophotometer in double-beam mode and a Haake circulating water bath, which was regulated manually. The sample cuvette temperature was monitored with a glass-embedded thermistor in the cuvette. The $T_{m}$ determined in $0.1 \times \mathrm{SSC}$ was converted to the expected $T_{m}$ in $1 \times \mathrm{SSC}$ by adding $15.4^{\circ} \mathrm{C}$, as described by Mandel and Marmur (11). The $\mathrm{G}+\mathrm{C}$ content was calculated by the formula of Marmur and Doty (13). $T_{m}$ analysis was performed on DNA from five new strains. These strains (strains F-100, I-9, BE-4, P3L-5, and TE-10) were selected to include one strain for each different origin from which the 16 isolates studied were obtained. The DNAs of B. polymyxa LMD $24.16^{\mathrm{T}}, B$. macerans NCTC $6355^{\mathrm{T}}$, and nitrogen-fixing Bacillus sp. strain Hino were also analyzed as references. All experiments were performed at least three times, and mean values and standard deviations were then calculated. Protein-free ribonuclease-treated Escherichia coli DNA (type 262109; Calbiochem-Behring) was used as a control and had a $T_{m}$ of $74.8^{\circ} \mathrm{C}$, corresponding to a $\mathrm{G}+\mathrm{C}$ content of $51.0 \mathrm{~mol} \%$.
Nitrogen fixation. Acetylene reduction was tested by measuring the ethylene production of cultures in $18-\mathrm{ml}$ vials as described previously (20). The medium employed was a modification of the semisolid glucose-malate medium of Patriquin et al. (15), in which malate, $\mathrm{CaCl}_{2}$, and $\mathrm{KOH}$ were omitted, the agar and glucose concentrations were doubled, and $1 \% \mathrm{CaCO}_{3}$ was added to stabilize the $\mathrm{pH}$. The vials were incubated for $24 \mathrm{~h}$ at $32^{\circ} \mathrm{C}$, after which acetylene was introduced. Readings were made after $1 \mathrm{~h}$ at $32^{\circ} \mathrm{C}$.

Nitrogen fixation was confirmed by micro-Kjeldahl analysis of 5-day-old cultures in the semisolid medium. These cultures had ceased to reduce acetylene, and the glucose of the medium had been completely depleted. Vials inoculated from heat-killed cultures were used as controls. Six replicate cultures were tested for each strain.

The influence of nitrate on acetylene reduction was determined by testing for acetylene reduction, using the modified Patriquin medium supplemented with up to $0.5 \% \mathrm{NaNO}_{3}$.

\section{RESULTS AND DISCUSSION}

Previous reports $(9,14,19,20)$ clearly show the difficulty encountered in identifying to species level nitrogen-fixing Bacillus isolates that differ from well-accepted Bacillus species. Thus, nitrogen-fixing Bacillus $\mathrm{sp}$. strain Hino was very tentatively classified as $B$. polymyxa (9), but the authors warned that it was different from this species in many respects, including $\mathrm{G}+\mathrm{C}$ content. However, a major taxonomic problem was the existence of only one representative strain, and Ouelette et al. (14) suggested that a final conclusion regarding the taxonomic position of this strain should await the isolation and description of additional similar strains. No other strains with characteristics similar to those of strain Hino have been described, except for the 16 strains isolated in our laboratory.

These strains were isolated from at least five different localities, indicating a geographical and ecological spread (Table 1 ). The six strains obtained roughly 3 years ago have maintained their properties up to now. Ten additional strains isolated very recently are identical to this group. Nitrogenfixing Bacillus sp. strain Hino, which was isolated from Japanese soil, was described in 1958 and has been kept in the laboratory since then. This strain is similar to our isolates. This group of strains belongs to the genus Bacillus, since their cells are rod shaped, they grow and form spores 
aerobically, and they are catalase positive. They are phenotypically related to $B$. polymyxa and $B$. macerans, but differ from these and other Bacillus species in many respects. Therefore, the conditions for defining a new species, as described by Gordon (5), seem to have been fulfilled. We propose that this species be named Bacillus azotofixans. A species description is given below.

Bacillus azotofixans n. sp. (a. zo. to. fix'ans. Gr. n. azote nitrogen; M.L. part. adj. fixans fixing, to hold in place; N.L. adj. azotofixans nitrogen fixing) cells are straight rods. After 24 to $48 \mathrm{~h}$ in GB broth, they occur singly and are weakly motile. The cells are 3 to 6 by $1 \mu \mathrm{m}$. In older GB broth cultures, long forms are produced. Strains sporulate well after 5 days on aerobic GB agar; in growth obtained from agar slants, the bulk of the organisms occur as spores. The spores are oval to ellipsoidal and predominantly central to subterminal and distend the sporangium to spindle shape
(Fig. 1). Capsules with discrete boundaries are produced. Aerobic cultures in medium supplemented with $0.1 \%$ $\left(\mathrm{NH}_{4}\right)_{2} \mathrm{HPO}_{4}$ contain inclusions of polyphosphate. Young (24-h) GB broth cultures are gram variable, containing both gram-positive and gram-negative cells. On GB agar under both aerobic and anaerobic conditions, colonies develop after $48 \mathrm{~h}$ at $32^{\circ} \mathrm{C}$. Colonies are 1 to $2 \mathrm{~mm}$ in diameter, whitish, circular to slightly irregular, and convex, with entire to undulate margins. They are mucoid and opaque, with a butyrous texture, and do not adhere to the agar. Colonies gradually become flatter and duller, and after 2 weeks reveal three to five concentric rings when viewed by transmitted light. Strains produce moderate growth after $48 \mathrm{~h}$ of anaerobic incubation on nitrogen-free thiamine-biotin agar (20). Under aerobic conditions, little or no growth is produced in nutrient broth or on the agar of Gordon et al. (6). TY broth and agar (22) permit moderate growth. Abundant growth is
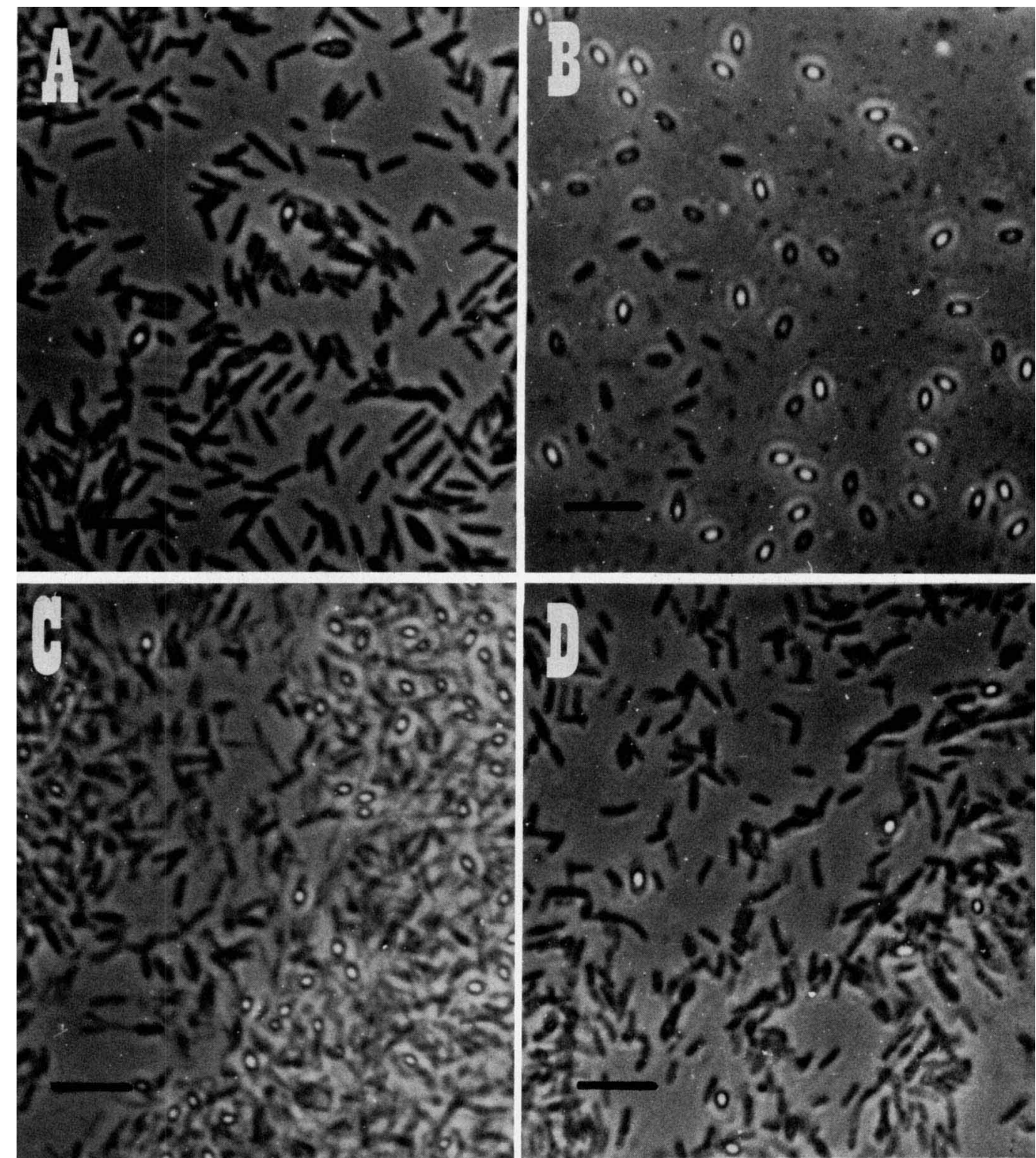

FIG. 1. Photomicrographs of wet mounts of sporulated cultures of B. azotofixans. (A) Strain F-100. (B) Strain BE-4. (C) Strain P3L-5 ${ }^{\mathrm{T}}$. (D) Strain TE-10. Bar $=10 \mu \mathrm{m}$. 
TABLE 2. DNA base compositions of five selected strains and three reference strains

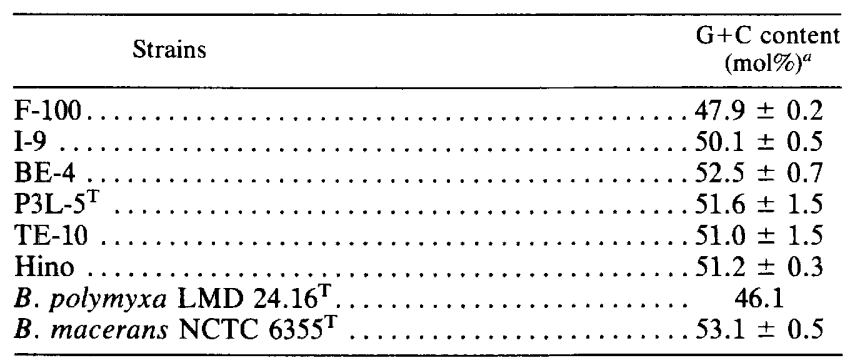

${ }^{a}$ Triplicate determinations in $0.1 \times$ SSC were calculated by the method of Mandel and Marmur (11).

produced after 24 to $48 \mathrm{~h}$ in GB broth. Visible growth occurs in a pellet on the bottom. The minimum and maximum temperatures for growth are 15 to 20 and 37 to $40^{\circ} \mathrm{C}$, respectively. No growth occurs at 10 or $42^{\circ} \mathrm{C}$. Moderate growth is produced at $\mathrm{pH}$ 5.7. Strains grow in the presence of $1 \% \mathrm{NaCl}$. At 2 and $3 \% \mathrm{NaCl}$, variable growth occurs. Growth is inhibited by $5 \% \mathrm{NaCl}$. No growth occurs in the presence of $0.001 \%$ lysozyme. Facultatively anaerobic. Aerobic growth is catalase positive and oxidase negative. Voges-Proskauer positive. Voges-Proskauer broth acidified to $\mathrm{pH} 4.5$ to 5.1. Acid and gas are produced from glucose, sucrose, galactose, maltose, raffinose, cellobiose, inulin, and mannitol. Acid and gas are not produced from xylose, arabinose, lactose, ribose, sorbose, and glycerol. Nitrate is not reduced. Citrate is not utilized as a carbon source. Casein and pectin are not decomposed. Gelatin is not liquefied. Tyrosine is not decomposed. Starch hydrolysis is negative, but slight clearing of the medium occurs beneath colonies. Dihydroxyacetone is not produced from glycerol. No crystalline dextrins are formed in rolled oat medium. Nitrogen is fixed under anaerobic conditions. Not susceptible to B. polymyxa typing phages EPy-1, SPy-1, and SPy-2. The base composition of the DNA ranges from 47.9 to 52.5 $\mathrm{mol} \% \mathrm{G}+\mathrm{C}$ (average, $50.7 \mathrm{~mol} \%$ ) (Table 2).

The type strain is strain ATCC 35681 (= P3L-5). The description of the type strain is the same as that given above for the species; the base composition of the DNA is $51.6 \pm$ $1.5 \mathrm{~mol} \%$.

Nitrogen fixation. For all newly isolated strains that grew on nitrogen-free isolation plates, the ability to fix molecular nitrogen was checked by assaying acetylene-reducing activity. As Table 3 shows, all isolates effectively reduced acetylene, and all values were in the range from 69.5 to $240.3 \mathrm{nmol}$ of ethylene per ml per $h$. These values were consistently higher than those obtained for selected $B$. polymyxa and $B$.
TABLE 3. Acetylene reduction and micro-Kjeldahl analysis of the isolated Bacillus strains and selected controls

\begin{tabular}{|c|c|c|}
\hline Strain & $\begin{array}{l}\text { Acetylene reduction } \\
\text { (nmol of ethylene } \\
\text { per } \mathrm{ml} \text { per } \mathrm{h})^{a}\end{array}$ & $\begin{array}{l}\text { Micro-Kjeldahl analysis } \\
\text { (mg of } \mathrm{N} \mathrm{per} \mathrm{g} \text { of } \\
\text { glucose })^{b}\end{array}$ \\
\hline F-100 & 194.5 & 3.7 \\
\hline F-102 & 87.5 & \\
\hline F-203 & 105.0 & \\
\hline F- 215 & 155.7 & \\
\hline F-1532 & 191.7 & \\
\hline I -9 & 162.5 & 3.6 \\
\hline BE-1 & 154.6 & \\
\hline BE-4 & 119.6 & 3.3 \\
\hline BE-5 & 108.6 & \\
\hline P3E-2 & 153.5 & \\
\hline P3E-20 & 69.5 & \\
\hline P3E-30 & 110.5 & \\
\hline P3L-3 & 109.7 & \\
\hline P3L-5 $5^{T}$ & 240.3 & 3.8 \\
\hline P5L-4 & 124.8 & \\
\hline TE-10 & 111.5 & 6.0 \\
\hline $\begin{array}{l}\text { B. polymyxa } \\
\text { NRRL B-371 }\end{array}$ & 35.7 & 0.4 \\
\hline $\begin{array}{l}\text { B. polymyxa } \\
\mathrm{L}\end{array}$ & 32.5 & 0.6 \\
\hline $\begin{array}{l}\text { B. polymyxa } \\
\text { LMD } 24.16^{\mathrm{T}}\end{array}$ & 0 & \\
\hline $\begin{array}{l}\text { B. macerans } \\
\text { P3L-2 }\end{array}$ & 15.6 & 0.2 \\
\hline $\begin{array}{l}\text { B. macerans } \\
\text { NCTC } 6355^{\mathrm{T}}\end{array}$ & 0 & \\
\hline
\end{tabular}

${ }^{a}$ Determinèd in semisolid medium after incubation for $24 \mathrm{~h}$ at $32^{\circ} \mathrm{C}$. Values are averages of triplicate vials.

${ }^{b}$ Determined by courtesy of J. Döbereiner, Embrapa, Rio de Janeiro State, Brazil.

macerans strains (Table 3), suggesting a higher efficiency of the nitrogen fixation process. Table 3 also shows that neither type strain reduced acetylene under these conditions, suggesting the absence of a nitrogen-fixing system. A microKjeldahl analysis performed on five selected isolates showed values in the range from 3.3 to $6.0 \mathrm{mg}$ of $\mathrm{N}$ per $\mathrm{g}$ of glucose, whereas reference strains $B$. polymyxa NRRL B-371, $B$. polymyxa $\mathrm{L}$, and $B$. macerans $\mathrm{P} 3 \mathrm{~L}-2$ fixed only 0.2 to $0.6 \mathrm{mg}$ of $\mathrm{N}$ per $\mathrm{g}$ of glucose (Table 3 ). This observation seems to confirm the higher efficiency of nitrogen fixation by the new isolates.

For four strains, nitrate $\left(\mathrm{NaNO}_{3}\right)$ at concentrations up to $0.5 \%$ did not influence the efficiency of acetylene reduction in semisolid medium, and at $0.5 \%$ nitrate the values indicating acetylene reduction were roughly equal to the control values (Table 4). This observation is in agreement with the

TABLE 4. Influence on acetylene reduction of $0.5 \%$ nitrate, $0.1 \%$ yeast extract, and thiamine plus biotin

\begin{tabular}{lcccccc}
\hline & \multicolumn{5}{c}{ Acetylene reduction (nmol of ethylene per ml per h) } \\
\cline { 2 - 7 } \multicolumn{1}{c}{ Strain } & 0\% Nitrate & $0.5 \%$ Nitrate & $\begin{array}{c}\text { 0\% Yeast } \\
\text { extract }\end{array}$ & $\begin{array}{c}0.1 \% \text { Yeast } \\
\text { extract }\end{array}$ & $\begin{array}{c}\text { No thiamine } \\
\text { plus biotin }\end{array}$ & $\begin{array}{c}\text { Thiamine }(1 \\
\mu \mathrm{g} / \mathrm{ml} \text { plus } \\
\mathrm{biotin}(\mu \mathrm{g} / \mathrm{ml})\end{array}$ \\
\hline F-100 & $149.4 \pm 23.2^{a}$ & $148.5 \pm 45.7$ & $96.5 \pm 48.0$ & $152.8 \pm 29.2$ & $96.5 \pm 48.0$ & $131.4 \pm 4.6$ \\
BE-4 & $71.3 \pm 12.0$ & $79.7 \pm 28.0$ & $80.8 \pm 9.5$ & $88.9 \pm 27.0$ & $77.8 \pm 4.6$ & $79.1 \pm 15.8$ \\
P3L-5 & $102.6 \pm 22.5$ & $77.3 \pm 15.4$ & $56.5 \pm 21.4$ & $102.6 \pm 22.5$ & $69.1 \pm 2.2$ & $77.2 \pm 15.7$ \\
TE-10 & $75.1 \pm 16.7$ & $68.2 \pm 21.1$ & $48.7 \pm 28.6$ & $75.1 \pm 16.7$ & $48.7 \pm 28.6$ & $45.9 \pm 30.4$ \\
B. polymyxa NRRL & $13.2 \pm 1.0$ & 0 & 0 & $13.2 \pm 1.0$ & 0 & 0 \\
$\quad$ B-371 & $13.6 \pm 1.7$ & 0 & 0 & $13.6 \pm 1.7$ & 0 & 0 \\
B. macerans P3L-2 & & 0 & & & & 0 \\
\hline
\end{tabular}

\footnotetext{
${ }^{a}$ Results are means \pm standard deviations of three different experiments.
} 
observed absence of a nitrate reductase in these strains. Acetylene reduction by $B$. polymyxa NRRL B-371 and $B$. macerans P3L-2 (both nitrate reducers) was completely inhibited by $0.5 \%$ nitrate.

Omission of $0.1 \%$ yeast extract from the semisolid modified Patriquin medium did not substantially lower the efficiency of acetylene reduction by the four selected strains (Table 4), although somewhat lower values were generally observed in the vials that lacked yeast extract. Acetylene reduction by reference strains $B$. polymyxa NRRL B-371 and $B$. macerans P3L-2 did not occur without yeast extract (Table 4). Addition of $1 \mu \mathrm{g}$ of thiamine per $\mathrm{ml}$ and $1 \mu \mathrm{g}$ of biotin per $\mathrm{ml}$ to the medium lacking yeast extract did not result in a substantial increase in acetylene-reducing efficiency (Table 4), suggesting that nitrogen fixation by our strains did not depend on these vitamins. Also, acetylene reduction by $B$. polymyxa NRRL B-371 and B. macerans P3L-2 was not stimulated by these vitamins.

As Table 5 shows, 12 biochemical characteristics other than nitrogen fixation separate $B$. azotofixans from $B$. polymyxa. These (negative) properties are production of dihydroxyacetone, nitrate reduction, production of acid and gas from xylose, arabinose, lactose, ribose, and glycerol, growth in $0.001 \%$ lysozyme, liquefaction of gelatin, hydrolysis of starch, and decomposition of casein and pectin. Furthermore, $B$. azotofixans is resistant to $B$. polymyxa phages. $B$. azotofixans differs from $B$. macerans by 12 properties. These include negative properties (production of crystalline dextrins; hydrolysis of starch; nitrate reduction; decomposition of pectin; growth at $45^{\circ} \mathrm{C}$; production of acid and gas from xylose, arabinose, lactose, ribose, and glycerol) and a positive property (Voges-Proskauer test). Furthermore, the spore position of $B$. azotofixans is central to subterminal instead of subterminal to terminal. Also, the observed $G+C$ contents were higher than the value determined for $B$. polymyxa LMD $24.16^{\mathrm{T}}$ DNA and were, with the possible exception of strain F-100, beyond the upper limit of the range reported for $B$. polymyxa DNA $(8,14)$. On the other hand, these values, although somewhat lower than the value determined for $B$. macerans NCTC $6355^{\mathrm{T}}$ DNA (Table 2), partially coincided with the range reported for $B$. macerans $(8,14)$.

A set of characteristics essential for membership in $B$. azotofixans is contained in the following short description: facultatively anaerobic endospore-forming rods that have central to subterminal spores bulging the sporangia to a spindle shape and are capable of fixing nitrogen very efficiently; strongly fermentative, producing acid and gas from glucose and mannitol but not from xylose and arabinose; Voges-Proskauer positive; nitrate reductase negative; no production of dihydroxyacetone; no production of crystalline dextrins; average $\mathrm{G}+\mathrm{C}$ content, $50.7 \pm 1.6 \mathrm{~mol} \%$ (six strains, including strain Hino).

The strains in this nitrogen-fixing species may be interesting to microbiologists, agronomists, and microbial ecologists alike, since they fix nitrogen efficiently, produce resistant forms, and are apparently widespread in soil, having been isolated in five different localities in Brazil and also in Japan. The fact that these strains were isolated both from nonrhizosphere soil and from grass roots suggests that they may occur either as free-living bacteria or as root-associated bacteria. Furthermore, they fix nitrogen efficiently in the presence of nitrate, and nitrogen fixation is not dependent on yeast extract or thiamin plus biotin.

\section{ACKNOWLEDGMENTS}

We are particularly indebted to Johanna Döbereiner for her help and stimulation. We also thank R. E. Gordon for confirming some of

TABLE 5. Differential characteristics of $B$. azotofixans, B. polymyxa, and B. macerans

\begin{tabular}{|c|c|c|c|}
\hline Characteristics & B. azotofixans & B. polymyxa $a^{a}$ & B. macerans ${ }^{b}$ \\
\hline Nitrogen fixation & $++^{c}$ & $\mathrm{v}$ & $\mathrm{v}$ \\
\hline $\mathrm{G}+\mathrm{C}$ content range (mol\%) & $47.9-52.5$ & $\begin{array}{r}43.1-45.6 \\
(44-48)^{d}\end{array}$ & $\begin{array}{l}49-51 \\
(50-54)^{d}\end{array}$ \\
\hline Spore position ${ }^{e}$ & C-ST & C-T & ST-T \\
\hline Voges-Proskauer test & + & + & - \\
\hline \multicolumn{4}{|l|}{ Acid and gas produced from: } \\
\hline Xylose & - & + & + \\
\hline Arabinose & - & + & + \\
\hline Lactose & - & $+^{f}$ & $+^{f}$ \\
\hline Ribose & - & $+^{f}$ & $+f$ \\
\hline Glycerol & - & $t^{f}$ & $+^{f}$ \\
\hline Growth at $45^{\circ} \mathrm{C}$ & - & - & + \\
\hline Growth in $0.001 \%$ lysozyme & - & $\mathrm{v}$ & - \\
\hline Nitrate reduction & - & + & + \\
\hline Starch hydrolysis & w- & + & + \\
\hline Decomposition of casein & - & + & - \\
\hline Liquefaction of gelatin & - & $t^{f}$ & \\
\hline Decomposition of pectin & - & + & + \\
\hline \multicolumn{4}{|l|}{ Production of: } \\
\hline Crystalline dextrins & - & - & + \\
\hline Dihydroxyacetone & - & + & - \\
\hline $\begin{array}{l}\text { Susceptibility to phages } \\
\text { EPy-1, SPy-1, and SPy-2 }\end{array}$ & - & +8 & - \\
\hline
\end{tabular}

${ }^{a}$ Unless indicated otherwise, the data are from references 4 and 6 and were confirmed in our laboratory with $B$. polymyxa LMD $24.16^{\mathrm{T}}, B$. polymyxa L, and B. macerans NCTC $6355^{\mathrm{T}}$

${ }^{b}$ Data from reference 14.

$c+$, Positive; - , negative; $v$, variable; $w-$, very weak to negative.

${ }^{d}$ Data from reference 14 ; data in parentheses from reference 8.

${ }^{e} \mathrm{C}-\mathrm{ST}$, Central to subterminal; C-T, central to terminal; ST-T, subterminal to terminal.

${ }^{f}$ Data obtained in our laboratory.

${ }^{g}$ Data from reference 21. 
our results and for her helpful comments, H. Rocha for kindly providing the $T_{m}$ facilities, and A. Drosdowicz for the use of the gas chromatograph. Thanks are also due to all colleagues who provided strains.

This work was supported by grants from the National Research Council of Brazil (CNPq) and FINEP.

\section{LITERATURE CITED}

1. Abdel Wahab, A. M. 1980 . Characterization of nitrogen-fixing $\left(\mathrm{C}_{2} \mathrm{H}_{2}\right.$-reducing) Bacillus species from Egyptian soils. Z. Allg. Mikrobiol. 20:487-494.

2. Baldani, V. L. D., and J. Döbereiner. 1980. Host-plant specificity in the infection of cereals with Azospirillum spp. Soil Biol. Biochem. 12:433-439.

3. Doetsch, R. N. 1981. Determinative methods of light microscopy, p. 21-33. In P. Gerhardt et al. (ed.), Manual of methods for general microbiology. American Society for Microbiology, Washington, D.C.

4. Gibson, T., and R. E. Gordon. 1974. Bacillus, p. 529-551. In R. E. Buchanan and N. E. Gibbons (ed.), Bergey's manual of determinative bacteriology, 8th ed. The Williams \& Wilkins Co., Baltimore.

5. Gordon, R. E. 1978. A species definition. Int. J. Syst. Bacteriol. 28:605-607.

6. Gordon, R. E., W. C. Haynes, and H.-N. Pang. 1973. The genus Bacillus. Agriculture Handbook 427. Agriculture Research Service, U.S. Department of Agriculture, Washington, D.C.

7. Grau, F. H., and P. W. Wilson. 1962. Physiology of nitrogen fixation by Bacillus polymyxa. J. Bacteriol. 83:490-496.

8. Hill, L. R. 1966. An index to deoxyribonucleic acid base compositions of bacterial species. J. Gen. Microbiol. 44:419437.

9. Hino, S., and P. W. Wilson. 1958. Nitrogen fixation by a facultative Bacillus. J. Bacteriol. 45:403-408.

10. Line, M. A., and M. W. Loutit. 1971. Nonsymbiotic nitrogenfixing organisms from some New Zealand tussock-grassland soils. J. Gen. Microbiol. 66:309-318.

11. Mandel, M., and J. Marmur. 1968. Use of ultraviolet absorbance-temperature profile for determining the guanine plus cytosine content of DNA. Methods Enzymol. 12B:195-206.
12. Marmur, J. 1961. A procedure for the isolation of deoxyribonucleic acid from microorganisms. J. Mol. Biol. 3:205-218.

13. Marmur, J., and P. Doty. 1962. Determination of the base composition of deoxyribonucleic acid from its thermal denaturation temperature. J. Mol. Biol. 5:109-118.

14. Ouellette, C. A., R. H. Burris, and P. W. Wilson. 1969. Deoxyribonucleic acid base composition of species of Klebsiella, Azotobacter and Bacillus. Antonie van Leeuwenhoek J. Microbiol. Serol. 35:275-286.

15. Patriquin, D. G., L. A. Gracioli, and A. P. Ruschel. 1980. Nitrogenase activity of sugar cane propagated from stem cutting in sterile vermiculite. Soil Biol. Biochem. 12:413-417.

16. Rennie, R. J. 1980. Dinitrogen-fixing bacteria: computer-assisted identification of soil isolates. Can. J. Microbiol. 26:12751282.

17. Rennie, R. J. 1981. A single medium for the isolation of acetylene-reducing (dinitrogen-fixing) bacteria from soils. Can. J. Microbiol. 27:6-14.

18. Rennie, R. J., J. R. Freitas, and A. P. Ruschel. 1982. Isolation and identification of $\mathbf{N}_{2}$-fixing bacteria associated with sugar cane (Saccharum sp.). Can. J. Microbiol. 28:462-467.

19. Rhodes-Roberts, M. E. 1981. The taxonomy of some nitrogenfixing Bacillus species with special reference to nitrogen fixation, p. 315-335. In R. C. W. Berkeley and M. Goodfellow (ed.), The aerobic endospore-forming bacteria: classification and identification. Academic Press, Inc., London.

20. Seldin, L., J. D. Van Elsas, and E. G. C. Penido. 1983. Bacillus nitrogen fixers from Brazilian soils. Plant Soil 70:243-255.

21. Seldin, L., J. D. Van Elsas, and E. G. C. Penido. 1984. Bacillus polymyxa bacteriophages from Brazilian soils. Antonie van Leeuwenhoek J. Microbiol. Serol. 50:39-51.

22. Van Elsas, J. D., and E. G. C. Penido. 1981. Isolation and characterization of Bacillus pumilus phages from Brazilian soil. Zentralbl. Bakteriol. Parasitenkd. Infektionskr. Hyg. Abt. 2 136:581-589.

23. Witz, D. F., R. W. Detroy, and P. W. Wilson. 1967. Nitrogen fixation by growing cells and cell-free extracts of the Bacillaceae. Arch. Mikrobiol. 55:369-381.

24. Wullstein, L. H., M. L. Bruening, and W. B. Bollen. 1979. Nitrogen fixation associated with sand grain root sheaths (rhizosheaths) of certain xeric grasses. Physiol. Plant. 46:1-4. 